\title{
Faktor-faktor yang berhubungan dengan kadar malondialdehyde plasma pada penyandang diabetes mellitus tipe 2
}

\author{
Factors associated to plasma malondialdehyde level in type 2 diabetes mellitus
}

Nazarina ${ }^{1}$, Reviana Christijani', Yunita Diana Sari ${ }^{1}$

\begin{abstract}
Background: Diabetic is associated with the risk of having lipid peroxidation causing macro and micro vascular diseases. Malondialdehyde (MDA) is a mutagen product of lipid peroxidation.

Objective: This research was to identify some factors associated to plasma MDA (P-MDA) level in type 2 diabetes mellitus.

Method: Eighty two subjects were randomly recruited. Subjets were members of Persadia, physical training club for diabetic at Mardjoeki Mahdi Hospital in Bogor. Data of fruits, vegetables, and nuts-legumes-seeds consumption were collected by interviewing using semi quantitative food frequency questionnaires. Fasting blood glucose and plasma MDA were assayed using Wills method, based on the reaction of thiobarbituric acid. Other data such as physical training, smoking status, and diseases history were collected by interviewing using structured questionnaires. Nutritional status data was determined as body mass index. All data was analyzed using Odds Ratio (OR) and logistic regression test to identify the dominant factors contributed to P-MDA level.

Results: Factors that contribute to P-MDA level is vegetables, nuts-legumes-seeds consumption and physical training. Consuming vegetables less than $300 \mathrm{~g} / \mathrm{d}$ and nuts-legumes-seeds less than 2.5 servings/d are associated significantly with having high level of $P-M D A(\geq 0.8 \mathrm{nmol} / \mathrm{L})$, respectively $O R=5(95 \% \mathrm{Cl}: 1.154-22.02)$ and $\mathrm{OR}=4.8(95 \% \mathrm{Cl}: 1.26-18.57)$. Not having physical activity routinely is risk for having high level $P-M D A(O R=1.3 ; 95 \% C l: 1.12-1.45)$. Those factors are associated to P-MDA level independently.

Conclusion: Vegetables and nuts-legumes-seeds consumption have a significant contribution to P-MDA level, it is important to know further which type and chemical content in those food that can prevent lipid peroxidation.
\end{abstract}

KEY WORDS: type 2 diabetes mellitus, plasma MDA, vegetables, nuts-legumes-seeds, physical training

\begin{abstract}
ABSTRAK
Latar belakang: Malondialdehyde merupakan produk mutagen dari peroksidasi lipid. Oleh karena itu, kadar MDA yang tinggi berhubungan dengan tingginya kejadian peroksidasi lipid. Pada penyandang diabetes mellitus (DM), peroksidasi lipid berhubungan dengan patogenesis komplikasi kronis makro dan mikrovaskular.

Tujuan: Penelitian ini dilakukan untuk mengetahui faktor yang berhubungan dengan kadar MDA plasma (MDA-P) pada penyandang DM tipe 2.

Metode: Sebanyak 82 subjek yaitu anggota Persadia unit Rumah Sakit Mardjoeki Mahdi direkrut secara random. Data konsumsi buah, sayur, kacang-biji-polong dalam 1 bulan terakhir dikumpulkan dengan wawancara menggunakan semi quantitative food frequency questionnaires. Kadar gula darah puasa dianalisa dengan metode enzimatik dan MDA-P dengan metode Wills berdasarkan reaksi dengan thiobarbituric acid. Data latihan fisik, status perokok aktif/pasif, dan riwayat penyakit diperoleh dengan wawancara menggunakan kuesioner. Status gizi ditentukan berdasarkan indeks massa tubuh yang diperoleh dari pengukuran berat badan dan tinggi badan $(\mathrm{kg} / \mathrm{m} 2)$. Data yang terkumpul diolah menggunakan uji odds ratio (OR) dan uji regresi logistik untuk mengetahui faktor-faktor yang dominan memberikan kontribusi terhadap kadar MDA-P.

Hasil: Konsumsi sayur kurang dari 300 g/hari, kacang-biji-polong kurang dari 2,5 porsi sehari, dan tidak rutin melakukan latihan fisik, berisiko memiliki kadar MDA-P tinggi dengan nilai OR masing-masing 5; 4,8; dan 1,3 ( $p=0,042 ; p=0,028$; $p=0,028$ ). Hasil uji multivariat regresi logistik tidak memperlihatkan adanya faktor dominan yang berhubungan dengan kadar MDA-P penyandang DM tipe 2, tetapi hubungan ketiga faktor tersebut terhadap MDA-P terjadi secara bebas (independen; $p>0,05$ ).

Simpulan: Konsumsi sayur dan kacang-biji-polong menunjukkan hubungan yang bermakna terhadap kadar MDA-P. Perlu diteliti lebih jauh mengenai kandungan jenis dan zat kimiawi pada sayur dan kacang-biji-polong yang dapat mencegah peroksidasi lipid.
\end{abstract}

KATA KUNCI: diabetes mellitus tipe 2, MDA plasma, sayur, kacang-biji-polong, latihan fisik

\footnotetext{
${ }^{1}$ Korespondensi: Pusat Teknologi Terapan Kesehatan dan Epidemiologi Klinik, Badan Penelitian dan Pengembangan Kesehatan, Kementerian Kesehatan, JI. DR. Semeru No.63, Bogor 16112, e-mail: nazarina@litbangdepkes.go.id
} 


\section{PENDAHULUAN}

Penyakit diabetes mellitus (DM) berkaitan erat dengan tingginya mortalitas dan morbiditas sebagai akibat komplikasi makro dan mikrovaskuler yang diderita (1). Terjadinya komplikasi vaskuler kronis pada penyandang DM berhubungan dengan stres oksidatif yang merupakan salah satu konsekuensi dari keadaan hiperglisemia. Adanya hubungan antara stres oksidatif dengan komplikasi vaskuler karena stres oksidatif dapat menyebabkan terjadinya peroksidasi lipid yang mengakibatkan kerusakan pada membran sel $(1,2)$. Produk peroksidasi lipid adalah lipid peroksida yang bentuk mutagennya berupa malondialdehyde (MDA) dan lipofuscin (3).

Kadar malondialdehyde plasma (MDA-P) pada individu sehat adalah $0,8 \pm 0,20 \mu \mathrm{mol} / \mathrm{L}$ (4). Pada umumnya, penyandang DM memiliki kadar MDA-P yang lebih tinggi dibandingkan dengan individu sehat. Selanjutnya, kadar MDA-P lebih tinggi pada penyandang DM dengan komplikasi dibandingkan dengan yang tidak mengalami komplikasi. Bila dilihat dari tipe diabetesnya, penyandang DM tipe 2 (DMT2) memilki kadar MDA-P yang lebih tinggi dibandingkan tipe 1 (4-6).

Pada penyandang DM, stres oksidatif dapat dicegah dengan memperbaiki keadaan hiperglisemia. Latihan fisik yang bersifat endurance dapat memperbaiki keadaan hiperglisemia dengan cara meningkatkan sensitivitas insulin dan aktivitas enzim mitokondrial (7). Setiap kali latihan fisik aerobik dapat memberikan efek terhadap sensitivitas insulin selama $24-72$ jam tergantung dari durasi dan intensitas latihan fisik. Oleh karena itu, dianjurkan bagi penyandang DM untuk melakukan latihan fisik dengan jeda waktu tidak lebih dari 2 hari antara hari latihan fisik yang satu dengan yang lainnya (8). Latihan fisik yang dilakukan sebanyak 3-4 kali seminggu selama 1 jam oleh penyandang DMT2 yang memiliki durasi penyakit 1-10 tahun menunjukkan adanya penurunan kadar MDA secara bermakna (9).

Selain itu, antioksidan dengan jumlah yang optimal di dalam tubuh dapat menetralisir ataupun mencegah radikal bebas penyebab stres oksidatif. Bahan makanan sumber antioksidan pada umumnya adalah sayur, buah, biji, kacang, dan polong (10). Stres oksidatif di dalam tubuh juga dapat meningkat karena adanya pajanan terhadap asap rokok (11). Oleh karena penyandang DM berisiko tinggi terhadap terjadinya peroksidasi lipid maka penelitian ini dilakukan untuk mengetahui faktor-faktor yang berhubungan dengan kadar lipid peroksida yang diukur dalam bentuk MDA-P. Dengan diketahuinya faktor-faktor tersebut maka penyandang DM dapat mencegah tingginya kadar lipid peroksida sehingga tercapai kualitas hidup yang baik.

\section{BAHAN DAN METODE}

Penelitian dengan desain cross sectional ini dilaksanakan pada bulan September sampai dengan
Oktober 2011 dan telah mendapat persetujuan etik (KE.01.04/EC.238/2011) dari Komite Etik Badan Penelitian dan Pengembangan Kesehatan, Kementerian Kesehatan Indonesia. Populasi penelitian adalah penyandang diabetes mellitus tipe 2 yang merupakan anggota Persatuan Diabetes Indonesia (Persadia) unit Rumah Sakit (RS) DR. Marzoeki Mahdi Bogor. Subjek penelitian ini adalah anggota Persadia unit RS Marzoeki Mahdi Bogor yang memenuhi kriteria inklusi dan eksklusi penelitian. Kriteria inklusi penelitian adalah subjek yang pernah didiagnosis oleh dokter atau tenaga medis menyandang DMT2, berusia 35-68 tahun, serta bersedia mengikuti penelitian dengan menandatangani informed consent. Kriteria eksklusi penelitian adalah subjek yang sedang hamil atau menyusui.

Besar sampel minimal diperoleh berdasarkan hasil perhitungan dengan nilai tingkat kepercayaan $(\alpha) 95 \%$, standar deviasi $(\sigma)$ sebesar $4(6)$, dan nilai presisi $(d)$ sebesar 1 yaitu sebanyak 97 subjek. Namun, subjek yang bersedia berpartisipasi dalam penelitian hanya 82 subjek. Data karakteristik subjek seperti usia, jenis kelamin, pendidikan, pekerjaan, riwayat penyakit, status perokok aktif/pasif, dan penatalaksanaan DM (diit, latihan fisik, dan obat hipoglikemik oral) dikumpulkan dengan cara wawancara menggunakan kuesioner terstruktur. Dikatakan sebagai perokok aktif/pasif jika subjek merokok ataupun terpapar asap rokok setiap hari dalam satu bulan terakhir. Subjek termasuk dalam kategori rutin latihan fisik jika melakukan latihan fisik dalam 3 bulan terakhir sebanyak 3 hari (tidak consecutive) dalam seminggu dengan durasi 30-45 menit setiap latihan fisik.

Penentuan status gizi berdasarkan indikator indeks massa tubuh (IMT) yaitu berat badan dibagi kuadran tinggi badan $\left(\mathrm{kg} / \mathrm{m}^{2}\right)$. Pengukuran berat badan menggunakan timbangan berat badan Seca dengan ketelitian $0,1 \mathrm{~kg}$ dan tinggi badan meggunakan pita ukur tinggi badan dengan ketelitian $0,1 \mathrm{~cm}$. Status gizi dikategorikan menjadi gemuk dan tidak gemuk berdasarkan cut off point untuk Asia Pacific yaitu $23 \mathrm{~kg} / \mathrm{m}^{2}(12)$.

Informasi konsumsi buah, sayur, kacang-polongbiji dalam satu bulan terakhir dikumpulkan dengan cara wawancara menggunakan semi quantitative food frequency questionaire. Banyaknya sayur, buah, dan kacang-polong-biji yang dikonsumsi oleh subjek dalam satu bulan dikonversi menjadi rata-rata gram per hari ( $\mathrm{g} /$ hari). Konsumsi kacang-polong-biji diukur dalam satuan porsi. Satu porsi kacang-kacangan dan polong-polongan adalah 25 gram, tempe $50 \mathrm{~g}$, tahu $100 \mathrm{~g}$, dan biji-bijian sebanyak $10 \mathrm{~g}$.

Data glukosa darah dan MDA-P berasal dari plasma darah puasa yang dilakukan pada subjek yang sebelumnya berpuasa 10-11 jam. Darah diambil melalui vena kubital sebanyak $\pm 5 \mathrm{ml}$ dan dimasukkan ke dalam tabung vacutainer berisi Ethylene Diamine Tetraacetic Acid (EDTA). 
Darah disentrifus dengan kecepatan 3500 rpm selama 10 menit. Pemeriksaan glukosa darah puasa dianalisa dengan menggunakan metode enzimatik dan dibaca dengan spektrofotometer. Untuk keperluan pemeriksaan MDA-P, plasma darah yang diperoleh disimpan di dalam freezer dengan suhu $-20^{\circ} \mathrm{C}$ selama maksimal satu bulan sebelum dibawa dengan cooling box ke laboratorium Biokimia Universitas Indonesia, Jakarta untuk dianalisa kadar MDA-nya. Pemeriksaan MDA-P menggunakan metode Wills yaitu berdasarkan reaktifitas thiobarbituric acid (13). Cut off kadar MDA-P yang digunakan dalam penelitian ini adalah $0,8 \mu \mathrm{mol} / \mathrm{L}(4)$.

Uji Odds Ratio (OR) dengan 95\% Cl dilakukan untuk mengetahui faktor-faktor yang berhubungan dengan kadar MDA-P. Uji multivariat regresi logistik dilakukan untuk mengetahui faktor yang berhubungan dengan kadar MDA-P dan faktor pengganggu hubungan tersebut.

\section{HASIL}

Berdasarkan karakteristik subjek (Tabel 1), sebagian besar berjenis kelamin perempuan $(85 \%)$, bersuku Sunda $(65 \%)$, berusia lebih dari 45 tahun $(97,6 \%)$, dan tidak bekerja $(87 \%)$. Apabila dilihat dari pendidikan formal subjek, jumlah subjek yang berpendidikan sekolah lanjutan tingkat atas (SLTA) sedikit lebih banyak (43\%) dibandingkan yang berpendidikan sekolah dasar atau sekolah lanjutan tingkat pertama (SD/SLTP) (40\%), sedangkan yang tidak sekolah hanya 2 orang $(2,4 \%)$ dan sisanya berpendidikan perguruan tinggi (17\%). Hampir semua subjek penelitian (91\%) telah didiagnosis DMT2 oleh dokter ataupun tenaga medis selama lebih dari satu tahun dengan rerata 6,5 tahun. Hal yang menarik adalah bahwa meskipun subjek telah didiagnosis DMT2 cukup lama, tetapi lebih dari separuhnya (52\%) belum atau tidak pernah mendapatkan konsultasi diit DM (Tabel 1).

Hubungan yang tidak bermakna secara statistik $(p>0,05)$ terlihat pada variabel perokok aktif/pasif, kadar glukosa darah, dan status gizi (Tabel 2). Penatalaksanaan DM antara lain diit, latihan fisik, dan penggunaan obat hipoglikemik oral $(\mathrm{OHO})$, yang memberikan risiko terhadap tidak normalnya kadar MDA-P adalah tidak rutinnya subjek melakukan latihan fisik $(O R=1,3 ; p=0,028)$. Hal tersebut didukung oleh hasil penelitian yang menunjukkan bahwa semua subjek (100\%) yang tidak melakukan latihan fisik secara rutin memiliki kadar MDA-P tidak normal (Tabel 3). Hasil uji multivariat logistik regresi juga memperlihatkan hubungan antara latihan fisik dengan kadar MDA-P yang tidak dipengaruhi oleh faktor-faktor lainnya $(p>0,05)$.

Penggunaan $\mathrm{OHO}$ biasanya dilakukan bila kadar glukosa darah penyandang DM sulit dikontrol melalui diit dan latihan fisik atau olah raga. Subjek penelitian yang menggunakan $\mathrm{OHO}$ ataupun tidak, memiliki kadar MDA-P abnormal dengan proporsi yang hampir sama dan sangat
Tabel 1. Karakteristik subjek

\begin{tabular}{lc}
\hline \multicolumn{1}{c}{ Karakteristik } & $\mathbf{n}(\%)$ \\
\hline Jenis kelamin & $12(15)$ \\
Laki-laki & $70(85)$ \\
Perempuan & \\
Pendidikan & $33(40)$ \\
$\quad$ Tidaksekolah/ SD/SLTP & $35(43)$ \\
SLTA & $14(17)$ \\
PT & \\
Pekerjaan & $11(13)$ \\
$\quad$ Bekerja & $71(87)$ \\
$\quad$ Tidak bekerja & \\
Suku & $61(65)$ \\
$\quad$ Sunda & $13(22)$ \\
Jawa & $8(13)$ \\
Lainnya & \\
Usia (tahun) & $2(2,4)$ \\
$\quad<45$ & $80(97,6)$ \\
$\quad$ Z 45 & \\
Riwayat sakit jantung & $71(87)$ \\
Tidak & $11(13)$ \\
Ya & \\
Riwayat hipertensi & $62(76)$ \\
Tidak & $20(24)$ \\
Ya & \\
Riwayat gastritis kronis & $65(79)$ \\
Tidak & $17(21)$ \\
Ya & \\
Mendapat konsultasi diit & $43(52)$ \\
Tidak & $39(48)$ \\
Ya &
\end{tabular}

besar yaitu masing-masing $82 \%$ dan $86 \%$. Penggunaan $\mathrm{OHO}$ pada penelitian tidak memperlihatkan hubungan yang bermakna terhadap kadar MDA-P $(p>0,05)$. Demikian juga hubungan diit dengan kejadian kadar MDA-P yang tidak normal, tidak menunjukkan kemaknaan statistik $(p>0,05)$ (Tabel 3). Data diit pada penelitian ini hanya berdasarkan pernyataan bahwa subjek pernah menerima konsultasi diit DM dari tenaga medis. Namun, tidak ditanyakan lebih jauh mengenai kepatuhan subjek menjalankan diit DM yang diterimanya.

Diit DM umumnya menganjurkan makanan selingan berupa buah atau sayur. Subjek yang mengonsumsi buah kurang dari $400 \mathrm{~g} / \mathrm{hari}$ atau konsumsi buah dan sayur kurang dari $600 \mathrm{~g} / \mathrm{hari}$, kebanyakan memiliki kadar MDA-P tidak normal dengan masing-masing proporsi $84 \%$ dan $86 \%$. Sehingga, kurangnya konsumsi buah ataupun buah dan sayur belum dapat memperlihatkan risiko yang bermakna $(p>0,05)$ untuk terjadinya kadar MDA-P tidak normal (Tabel 4). Diit yang dideskripsikan sebagai konsumsi sayur ataupun kacang-polong-biji memperlihatkan hubungan yang bermakna terhadap kadar MDA-P. Subjek dengan konsumsi sayur kurang dari 300 $\mathrm{g} /$ hari memberikan risiko 5 kali lebih besar memiliki kadar MDA-P tidak normal dibandingkan dengan subjek yang mengonsumsi sayur lebih dari atau sama dengan $300 \mathrm{~g} / \mathrm{hari}$ 
Tabel 2. Hubungan perokok aktif/pasif dan kadar glukosa darah dengan kadar MDA-P subjek

\begin{tabular}{|c|c|c|c|c|c|}
\hline \multirow[b]{2}{*}{ Variabel } & \multicolumn{2}{|c|}{ Kadar MDA plasma } & \multirow[b]{2}{*}{ OR } & \multirow[b]{2}{*}{$95 \mathrm{Cl} \%$} & \multirow[b]{2}{*}{$\mathbf{p}$} \\
\hline & $\begin{array}{c}\text { Tidak normal } \\
\mathrm{n}(\%) \\
(\geq 0,8 \mu / \mathrm{ml}) \\
\end{array}$ & $\begin{array}{c}\text { Normal } \\
\mathrm{n}(\%) \\
(<0,8 \mu / \mathrm{ml})\end{array}$ & & & \\
\hline Perokok aktif/pasif & & & & & \\
\hline $\begin{array}{l}\text { Perokok aktif/ pasif } \\
\text { Bukan perokok aktif/pasif }\end{array}$ & $\begin{array}{l}56(82) \\
12(86)\end{array}$ & $\begin{array}{l}12(18) \\
2(14)\end{array}$ & 1,3 & 0,$25 ; 6,5$ & 0,56 \\
\hline Gula darah puasa & & & & & \\
\hline $\begin{array}{l}\text { Tidak normal } \\
\text { Normal }\end{array}$ & $\begin{array}{l}57(84) \\
11(83)\end{array}$ & $\begin{array}{l}11(16) \\
3(21)\end{array}$ & 1,4 & 0,$34 ; 5,91$ & 0,44 \\
\hline Status gizi & & & & & \\
\hline $\begin{array}{l}\text { Lebih }\left(\text { IMT } \geq 23 \mathrm{~kg} / \mathrm{m}^{2}\right) \\
\text { Tidak lebih }\left(\text { IMT }<23 \mathrm{~kg} / \mathrm{m}^{2}\right)\end{array}$ & $\begin{array}{l}51(82) \\
17(85)\end{array}$ & $\begin{array}{l}11(18) \\
3(15)\end{array}$ & 0,8 & 0,$20 ; 3,28$ & 0,54 \\
\hline
\end{tabular}

Tabel 3. Hubungan penatalaksanaan diabetes dengan kadar MDA-P subjek

\begin{tabular}{|c|c|c|c|c|c|}
\hline \multirow{3}{*}{ Tatalaksana diabetes } & \multicolumn{2}{|c|}{ Kadar MDA plasma } & \multirow{3}{*}{ OR } & \multirow{3}{*}{$95 \mathrm{Cl} \%$} & \multirow{3}{*}{$\mathbf{p}$} \\
\hline & $\begin{array}{c}\text { Tidak normal } \\
(\geq 0,8 \mu / \mathrm{ml})\end{array}$ & $\begin{array}{c}\text { Normal } \\
(<0,8 \mu / \mathrm{ml})\end{array}$ & & & \\
\hline & n (\%) & n (\%) & & & \\
\hline \multicolumn{6}{|l|}{ Obat hipoglikemik oral } \\
\hline $\begin{array}{l}\text { Tidak } \\
\text { Ya }\end{array}$ & $\begin{array}{l}12(86) \\
56(82)\end{array}$ & $\begin{array}{l}2(14) \\
12(18)\end{array}$ & 1,3 & 0,$254 ; 6,51$ & 0,551 \\
\hline \multicolumn{6}{|l|}{ Rutin latihan fisik } \\
\hline $\begin{array}{l}\text { Tidak } \\
\text { Ya }\end{array}$ & $\begin{array}{l}17(100) \\
51(79)\end{array}$ & $\begin{array}{c}0(0) \\
14(21)\end{array}$ & 1,3 & 1,$12 ; 1,45$ & $0,028^{*}$ \\
\hline \multicolumn{6}{|l|}{ Diit } \\
\hline $\begin{array}{l}\text { Tidak } \\
\text { Ya }\end{array}$ & $\begin{array}{l}35(81,4) \\
33(84,6)\end{array}$ & $\begin{array}{l}8(18,6) \\
6(15,4)\end{array}$ & 1,3 & 0,$39 ; 4,01$ & 0,78 \\
\hline
\end{tabular}

Keterangan: * signifikan $(p<0,05)$

Tabel 4. Hubungan konsumsi buah dan sayur dengan kadar MDA-P subjek

\begin{tabular}{|c|c|c|c|c|c|}
\hline \multirow{3}{*}{ Bahan makanan } & \multicolumn{2}{|c|}{ Kadar MDA Plasma } & \multirow{3}{*}{ OR } & \multirow{3}{*}{$95 \mathrm{Cl} \%$} & \multirow{3}{*}{$\mathbf{p}$} \\
\hline & $\begin{array}{c}\text { Normal } \\
(<0,8 \mu / \mathrm{ml})\end{array}$ & $\begin{array}{c}\text { Tidak normal } \\
(\geq 0,8 \mu / \mathrm{ml})\end{array}$ & & & \\
\hline & n (\%) & n (\%) & & & \\
\hline \multicolumn{6}{|l|}{ Buah } \\
\hline Kurang $(<400 \mathrm{~g})$ & $62(84)$ & $12(16)$ & 1,7 & 0,$31 ; 9,58$ & 0,412 \\
\hline Cukup $(\geq 400 \mathrm{~g})$ & $6(75)$ & $2(25)$ & & & \\
\hline \multicolumn{6}{|l|}{ Sayur } \\
\hline Kurang (<300 g) & $63(86)$ & $10(13)$ & 5,0 & 1,$154 ; 22,02$ & $0,042^{*}$ \\
\hline Cukup ( $\geq 300 \mathrm{~g})$ & $5(56)$ & $4(44)$ & & & \\
\hline \multicolumn{6}{|l|}{ Kacang-polong-biji } \\
\hline Kurang $(<2,5 p)$ & $61(87)$ & $9(13)$ & 4,8 & 1,$26 ; 18.57$ & $0,028^{*}$ \\
\hline Cukup $(\geq 2,5 p)$ & $7(58)$ & $5(42)$ & & & \\
\hline \multicolumn{6}{|l|}{ Buah-sayur } \\
\hline Kurang $(<600 \mathrm{~g})$ & $61(86)$ & $10(14)$ & 3,5 & 0,$86 ; 14,12$ & 0,087 \\
\hline Cukup ( $\geq 600 \mathrm{~g})$ & $7(64)$ & $4(36)$ & & & \\
\hline \multicolumn{6}{|c|}{ Buah-sayur-kacang-polong-biji } \\
\hline Kurang & $64(85,3)$ & $11(14,7)$ & 4,4 & 0,$85 ; 22,22$ & 0,076 \\
\hline Cukup & $4(57,1)$ & $3(42,9)$ & & & \\
\hline \multicolumn{6}{|l|}{ Suplemen } \\
\hline Tidak & $58(84)$ & $11(16)$ & 1,6 & 0,$37 ; 6,69$ & 0,388 \\
\hline $\mathrm{Ya}$ & $10(77)$ & $3(23)$ & & & \\
\hline
\end{tabular}


$(p=0,042)$. Proporsi subjek yang mengonsumsi kacangpolong-biji sebanyak 2,5 porsi/hari atau lebih masih sangat jarang (15\%), tetapi hasil analisis menunjukkan bahwa subjek yang mengonsumsi kacang-polong-biji kurang dari 2,5 porsi/hari berisiko 4,8 kali lebih besar memiliki kadar MDA-P tidak normal dibandingkan dengan subjek yang mengonsumsi lebih dari atau sama dengan 2,5 porsi/ hari $(p=0,028)$. Hasil uji logistik regresi diperoleh bahwa hubungan antara konsumsi sayur ataupun kacang-polongbiji terhadap kadar MDA-P tidak dipengaruhi oleh faktorfaktor lainnya $(p>0,05)$.

Apabila konsumsi buah, sayur, dan kacang-polongbiji digabungkan, hasilnya memperlihatkan hubungan yang tidak bermakna $(p>0,05)$ terhadap kadar MDA-P. Asupan zat gizi selain diperoleh dari bahan makanan dapat pula diperoleh melalui suplemen. Suplemen antioksidan yang umumnya dikonsumsi oleh subjek penelitian ini adalah suplemen vitamin $\mathrm{C}$, vitamin $\mathrm{E}$, dan minyak ikan (omega 3). Jumlah subjek yang mengonsumsi suplemen pada penelitian ini masih sangat sedikit yaitu 13 dari 82 subjek sehingga dimungkinkan menunjukkan hubungan yang tidak bermakna antara konsumsi suplemen antioksidan dengan kadar MDA-P subjek $(p>0,05)$ (Tabel 4).

\section{BAHASAN}

Subjek penelitian sebagian besar berjenis kelamin perempuan, tidak bekerja, bersuku Sunda, dan sudah lama (>1 tahun) terdiagnosis DMT2. Usaha diit merupakan salah satu penatalaksanaan diabetes (14). Diit diabetes umumnya menganjurkan untuk mengonsumsi kacang/polong sebanyak 2,5 porsi/hari sebagai bagian dari makanan utama. Jenis kacang/polong yang sering dikonsumsi oleh subjek penelitian ini antara lain tempe, tahu, kacang tanah, kacang merah, dan kacang hijau. Hasil penelitian ini menunjukkan bahwa konsumsi kacang-polong-biji sebanyak 2,5 porsi/hari atau lebih dapat mengurangi risiko terjadinya peroksidasi lipid yang diukur dalam bentuk MDA-P $(p<0,05)$. Dimungkinkan mengonsumsi kacangpolong-biji sebanyak 2,5 porsi sehari atau lebih dapat meningkatkan status antioksidan di dalam tubuh subjek. Jenis antioksidan yang banyak dikandung oleh bahan makanan tersebut adalah antioksidan vitamin $\mathrm{E}$ (tokoferol) yang berfungsi sebagai scavenger yaitu mengubah radikal bebas menjadi non radikal bebas. Diketahui bahwa vitamin $E$ dapat membantu mencegah peroksidasi lipid sehingga kadar MDA-P tinggi (abnormal) dapat dicegah (15).

Fungsi tokoferol sebagai anti peroksidasi lipid dibuktikan oleh salah satu penelitian pada tikus berupa pemberian ekstrak polong dari kacang hijau dan adzuki bean yang mengandung tokoferol. Hasilnya menunjukkan bahwa adanya aktivitas antiperoksidasi lipid yang sangat kuat dan aktivitas scavenging superoksida anion yang sangat tinggi (16). Meskipun konsumsi kacang-polong-biji bermanfaat untuk mencegah peroksidasi lipid, tetapi subjek pada penelitian ini masih jarang (15\%) yang mengonsumsi kacang-polong-biji dalam jumlah yang cukup ( $\geq 2,5$ porsi) per harinya. Rendahnya asupan kacang-polong-biji pada subjek dimungkinkan oleh ketidaktahuan subjek mengenai diit DM karena hampir lebih dari separuh $(52,4 \%)$ subjek penelitian ini belum pernah mendapatkan konsultasi diit DM.

Sumber antioksidan makanan juga terdapat dalam sayuran dan buah. Efek protektif sayuran terhadap oksidatif stres antara lain ditunjukkan melalui pemberian ekstrak $B$ oleracea (kol merah) pada tikus diabetes yang hasilnya dapat menurunkan kadar malondialdehyde dan meningkatkan aktivitas katalase dan superoksida dismutase yang merupakan enzim antioksidan di ginjal (17). Namun, ternyata tidak semua sayur dapat mencegah lipid peroksidasi. Hal ini dibuktikan dengan pemberian jus tomat yang dapat menurunkan oksidasi LDL pada laki-laki sehat tetapi tidak untuk pemberian jus wortel dan bubuk bayam (18). Jenis sayuran yang sering dikonsumsi oleh subjek penelitian ini adalah labu siam, ketimun, dan wortel sebagai bagian dari makanan utama ataupun makanan selingan.

Hasil penelitian ini membuktikan bahwa konsumsi sayuran sebanyak 300 gram atau lebih per hari berhubungan bermakna dengan pencegahan kadar MDA-P tidak normal $(p<0,05)$ dan hasil uji logistik regresi memperlihatkan bahwa hubungan tersebut tidak dipengaruhi oleh faktorfaktor lainnya $(p>0,05)$. Pencegahan peroksidasi lipid melalui konsumsi sayur, mekanismenya dapat berupa peningkatan kapasitas antioksidan akibat antioksidan yang dikandung sayur atau melalui perbaikan glisemia darah akibat serat yang dikandungnya atau akibat kedua faktor tersebut yaitu antioksidan dan serat. Peningkatan konsumsi serat pada penyandang DM dapat memberikan manfaat dalam mengontrol glisemia darahnya (19). Suatu penelitian memperlihatkan bahwa pemberian serat berupa pektin dapat menurunkan serum MDA pada tikus yang diberi diit mengandung minyak teroksidasi $(p<0,05)(20)$.

Meskipun buah juga merupakan sumber antioksidan, ternyata hasil penelitian ini menunjukkan bahwa konsumsi buah tidak memberikan hubungan yang bermakna terhadap kadar MDA-P. Keadaan tersebut kemungkinan terjadi karena penggunaan cut off point buah sebesar 400 g/hari ( \pm 4 porsi) masih belum dapat menggambarkan asupan antioksidan yang cukup atau jenis buah yang dikonsumsi subjek penelitian ini belum bisa meningkatkan status antioksidan di dalam plasmanya. Jenis buah yang sering dikonsumsi pada subjek penelitian ini adalah pisang segar atau digoreng, jeruk, dan pepaya. Hasil penelitian ini yang perlu menjadi perhatian adalah masih banyaknya subjek (90\%) yang mengonsumsi buah dalam jumlah yang kurang (<400 g/hari). World Health Organization (WHO) menganjurkan untuk mengonsumsi sayur-buah 
sebanyak 500-600 g/hari untuk kesehatan. Hasil penelitian ini menunjukkan bahwa konsumsi sayur berhubungan bermakna tehadap kadar MDA-P subjek, tetapi pada saat konsumsi sayur digabungan dengan konsumsi buah $(600$ $\mathrm{g} /$ hari) maka hubungan yang bermakna terhadap MDA-P tidak terlihat $(p>0,05)$.

Apabila dilihat dari nilai cut off jumlah sayur dan buah (600 g/hari) yang dikonsumsi subjek pada penelitian ini, maka nilai tersebut masih lebih rendah dibandingkan dengan penelitian yang dilakukan di Amerika Serikat yaitu pemberian buah-sayur sebanyak 10 porsi sehari selama 15 hari yang dapat meningkatkan kapasitas antioksidan plasma yang diukur sebagai oxygen radical absorbance capacity (ORAC) (21). Meskipun terdapat penelitian lain di UK yang menunjukan bahwa jumlah buah-sayur (5 porsi) yang dikonsumsi lebih rendah dari penelitian ini, tetapi hasilnya menunjukkan peningkatan yang bermakna pada konsentrasi antioksidan $\alpha$-karoten, $\beta$-karoten, $\beta$-cryptoxanthin, dan asam askorbat plasma (22). Hal ini terjadi karena penelitian tersebut dilakukan selama 6 bulan sedangkan pada penelitian ini konsumsi buah dan sayur hanya dalam 1 bulan terakhir. Dengan demikian, agar konsumsi buah dan sayur dapat mencegah peroksidasi lipid perlu mempertimbangkan beberapa hal diantaranya adalah banyak, jenis, dan durasi serta frekuensi konsumsi buah dan sayur.

Pada penelitian ini, konsumsi suplemen tidak menunjukkan hubungan yang bermakna terhadap kadar MDA-P. Keadaan ini disebabkan oleh frekuensi, dosis, dan jenis suplemen antioksidan yang dikonsumsi oleh masingmasing subjek berbeda. Jenis suplemen antioksidan yang sering dikonsumsi subjek bervariasi yaitu suplemen vitamin $\mathrm{E}$, vitamin $\mathrm{C}$, atau asam lemak omega 3. Selain itu, dosis suplemen yang dikonsumsi tidak diketahui dengan pasti. Setiap jenis suplemen antioksidan memberikan efek yang berbeda terhadap penurunan kadar MDA. Seperti penelitian yang dilakukan pada tikus diabetes menunjukkan bahwa pemberian suplemen vitamin $A, E$, dan $C$ selama 4 minggu dapat menurunkan kadar MDA di plasma, hati, dan jantung sedangkan suplemen asam lemak omega 3 hanya memperlihatkan penurunan MDA di jantung (23).

Tingginya kadar MDA-P juga dapat dicegah dengan latihan fisik yang rutin, keadaan tersebut secara bebas (independent) berhubungan bermakna pada penelitian ini. Latihan fisik yang dilakukan subjek penelitian adalah senam sebanyak 3 kali seminggu yaitu hari senin, rabu, dan jum'at. Durasi senam adalah 45 menit termasuk pemanasan dan pendinginan. Hubungan antara latihan fisik dengan MDAjuga terlihat pada penelitian lainnya di Jamaika yaitu latihan fisik konvensional maupun yoga hatha yang dilakukan selama 6 bulan secara bermakna $(p<0,0001)$ dapat menurunkan konsentrasi MDA-P sebesar 18,1\% dan 19,9\%. Demikian pula glukosa darah puasa turun akibat latihan fisik konvensional dan yoga hatha yaitu masing-masing sebesar $27,43 \%$ dan $29,48 \%(p<0,0001)(9)$.
Hasil penelitian ini menunjukkan bahwa sebagian besar subjek $(82,9 \%)$ memiliki kadar glukosa darah puasa tinggi (>126 mg\%) yang dapat pula dikategorikan sebagai kadar gula darah tidak terkontrol, maka hubungan antara latihan fisik terhadap pencegahan peroksidasi lipid bukan disebabkan oleh terkontrolnya kadar glukosa darah melainkan lebih dimungkinkan karena adanya peningkatan kapasitas antioksidan di dalam tubuh. Penelitian di Italia membuktikan adanya korelasi positif antara rerata kadar glukosa darah harian dengan MDA-P $(p<0,01)$ dan peningkatan konsentrasi MDA-P terlihat pada pasien diabetes dengan kadar glukosa darah yang tidak terkontrol $(p<0,001)(24)$. Namun, kadar glukosa darah puasa pada subjek penelitian ini tidak memperlihatkan hubungan yang bermakna terhadap kadar MDA-P $(p>0,05)$. Keadaan tersebut dapat disebabkan oleh data glukosa darah yang diperoleh pada penelitian ini hanya berdasarkan satu kali pemeriksaan. Diketahui bahwa glukosa darah sangat berfluktuatif sehingga tidak mencerminkan rata-rata kadar glukosa darah harian.

Selain itu, kemungkinan penggunaan nilai cut off glukosa darah puasa pada penelitian ini masih rendah (126 $\mathrm{mg} \%$ ) sehingga belum cukup untuk menggambarkan hubungannya terhadap kadar MDA-P. Penelitian lain menggunakan cut off glukosa darah puasa $150 \mathrm{mg} / \mathrm{dl}$ dan hasilnya memperlihatkan bahwa subjek dengan kadar glukosa darah puasa kurang dari $150 \mathrm{mg} / \mathrm{dl}$ memiliki rata-rata kadar MDA lebih rendah $(2,74 \pm 0,32 \mu / \mathrm{ml})$ dibandingkan subjek dengan kadar glukosa darah puasa lebih dari atau sama dengan $150 \mathrm{mg} / \mathrm{dl}(4,15 \pm 0,37 \mu / \mathrm{ml}$; $\mathrm{p}<0,02)(25)$.

Salah satu cara untuk mengontrol kadar glukosa darah adalah dengan mengonsumsi obat antidiabetes atau dikenal sebagai obat hipoglikemik oral (OHO). Meskipun menurut hasil penelitian di Turki menunjukkan bahwa kadar MDA lebih tinggi pada pasien diabetes yang mengunakan $\mathrm{OHO}$, tetapi hubungan tersebut tidak bermakna $(p>0,05)$. Ternyata penelitian tersebut menggunakan subjek yang baru didiagnosis diabetes dan dibandingkan dengan subjek yang sehat (26). Pada penelitian ini, terlihat bahwa di antara subjek yang memiliki kadar MDA-P tidak normal, sedikit lebih banyak yang tidak menggunakan $\mathrm{OHO}$ $(86 \%)$ dibandingkan yang menggunakan $\mathrm{OHO}(82 \%)$. Namun, perbedaan proporsi tersebut belum cukup kuat untuk menggambarkan hubungan yang bermakna antara penggunaan $\mathrm{OHO}$ dengan kadar MDA-P.

Beberapa penelitian sebelumnya menunjukkan bahwa status gizi berupa IMT berhubungan bermakna dengan peroksidasi lipid yaitu penelitian di Jepang yang dilakukan pada subjek berusia 70 tahun ke atas dengan menggunakan cut off IMT sebesar $30 \mathrm{~kg} / \mathrm{m}^{2}$ serta penelitian di Kuwait yang menggunakan cut off IMT sebesar $40 \mathrm{~kg} / \mathrm{m}^{2}$ $(4,27,28)$. Pada penelitian ini, usia subjek berkisar antara 37-67 tahun dan menggunakan cutt off IMT sebesar 23 $\mathrm{kg} / \mathrm{m}^{2}$. Dengan demikian, dimungkinkan hasil penelitian ini 
belum cukup menggambarkan hubungan yang bermakna antara IMT dengan kadar MDA-P.

Lebih lanjut, keterkaitan merokok dengan kadar MDA disebabkan oleh asap rokok yang merupakan pencetus produksi radikal bebas oksigen $(29,30)$. Penelitian ini mencoba melihat tentang keterkaitan perokok aktif/pasif terhadap kadar MDA-P karena seperti perokok aktif, perokok pasif pun juga menghirup asap rokok. Hasil penelitian ini menunjukkan bahwa perokok aktif/pasif tidak memiliki hubungan yang bermakna terhadap kadar MDA-P. Hal tersebut dapat disebabkan oleh durasi pajanan asap rokok setiap harinya yang belum cukup menyebabkan peroksidasi lipid dan pajanan radikal bebas asap rokok atau jarak pajanan asap rokok dari sumber asap rokok ke perokok pasif cukup jauh. Pada penelitian ini, durasi perokok pasif terpapar asap rokok setiap harinya adalah 10-30 menit tetapi jarak pajanan asap rokok tidak diteliti.

\section{SIMPULAN DAN SARAN}

Faktor-faktor yang berhubungan bermakna terhadap risiko kadar MDA-P tinggi (tidak normal) adalah kurangnya konsumsi sayur (<300 g/hari) dan kacang-polong-biji (<2,5 porsi/hari), serta tidak rutin melakukan latihan fisik. Namun, tidak ada yang dominan dalam memberikan risiko terhadap kadar MDA-P tinggi, ketiga variabel tersebut berhubungan dengan MDA-P secara bebas atau tidak dipengaruhi oleh faktor-faktor lainnya.

Sebagian besar subjek dengan asupan sayur, buah, dan kacang-polong-biji yang tergolong rendah dapat disebabkan oleh masih banyaknya subjek penelitian yang belum pernah mendapat konsultasi diit. Melalui edukasi, penyandang DM dapat meningkatkan konsumsi sayur, kacang-polong-biji, dan buah serta meningkatkan rutinitas latihan fisik sehingga peroksidasi lipid dapat dicegah. Perlu diteliti lebih lanjut mengenai jenis kacang-polongbiji dan sayuran serta kandungan zat kimiawinya yang berperan dalam mencegah tingginya kadar lipid peroksida (MDA-P).

\section{UCAPAN TERIMA KASIH}

Peneliti mengucapkan terimakasih kepada Badan Penelitian dan Pengembangan Kesehatan, Kementerian Kesehatan yang telah mendanai penelitian ini dan Persadia yang telah memberikan izin penelitian di lingkungannya.

\section{RUJUKAN}

1. Adi S. The Importance of tight blood glucose control in cardiovascular complications. Progress in Diabetology and Related Disorders: from Bench to Clinical Pratice; Forum Diabetes Nasional III. Bandung: Perkeni; 2005.
2. Vecirel E, Januel C, Carreras M, Moulin P, Lagarde M. Diabetic patients without vascular complications display enhanced basal platelet activation and decreased antioksidan status. Diabetes 2004;53(4):1046-51.

3. Wickens AP. Ageing and free radical theory. Respir Physiol 2001;128(3):379-91.

4. Lapolla A, Piarulli F, Sartore G, Ceriello A, Ragazzi E, Reitano R, Baccarin L, Laverda B, Fedele D. Advanced glycation end products and antioxidant status in type 2 diabetic patiet with and without peripheral arthery disease. Diabetes Care 2007;30(3):670-6.

5. Ozben T, Nacitarhan S, Tuncer N. Plasma and urine malondialdehyde level in non-insulin-dependentdiabetic-patients with and without microalbuminuria. Int J Clin Lab Res 1995;25(3):162-4.

6. Suryawanshi NP, Bhutey AK, Nagdeote AN, Jadhav AA, Manookar GS. Study of lipid peroxide and lipid profile in diabetes mellitus. Indian $\mathrm{J}$ Clin Biochem 2006;21(1):126-30.

7. Lauza IR, Short DK, Short KR, Raghavalaimal S, Basu R, Joyner MJ, McConnel JP, Nair KS. Endurance exercise as countermeasure for aging. Diabetes 2008;57(11):2933-42.

8. Sigal RJ, Kenny GP, Wasserman DH, CastanedaSceppa C, White RD. Physical activity/exercise and type 2 diabetes: a consensus statement from the American Diabetes Association. Diabetes Care 2006;29(6):1433-8.

9. Gordon LA, Morrison EY, McGrowder DA, Young R, Fraser YT, Zamora EM, Alexander-Lindo RL, Irving RR. Effect of exercise theraphy on lipid profile and oxidative stress indicators in patients with type 2 diabetes. BMC Complement Altern Med 2008;8:21.

10. O'Connell BS. Select vitamin and minerals in the management of diabetes. Diabetes Spectrum 2001;14(3):133-48.

11. Bloomer RJ. Decreased blood antioxidant capacity and increased lipid peroxidation in young cigarette smokers compared to nonsmokers: impact of dietary intake. Nutr J 2007;6:39.

12. WHO Expert Consultation. Appropiate body-mass index for Asian populations and its implications for policy and intervention strategies. Lancet 2004;363(9412):157-63.

13. Bagian Biokimia UI. Radikal bebas dan antoksidan dalam kesehatan, dasar, aplikasi, dan pemanfaatan bahan alam. Jakarta: UI Biokimia; 2001.

14. Almatsier S, Instalasi Gizi Perjan RS Dr. Cipto Mangunkusumo, Asosiasi Dietisien Indonesia. Penuntun diet. Jakarta: Gramedia; 2001.

15. Maguire LS, O'Sullivan SM, Galvin K, O'Connor TP, O'Brien NM. Fatty acid profile, tocopherol, squalene and phytosterol content of walnuts, almonds, peanuts, hazelnuts and the macadamia nut. Int J Food Sci Nutr 2004;55(3):171-8. 
16. Lin CC, Wang SJ, Yang JJ, Chang CH. Evaluation of the antioxidant activity of legumes. Pharmaceutical Biology 2001;39(4):300-4.

17. Kataya HA, Hamza AA. Red Cabbage (Brassica Oleracea) ameliorates diabetic nephropathy in rat. Evid Based Complement Alternat Med 2008;5(3):281-7.

18. BubA, Watzi B, Abrahamse L, Delicee H,Adam S, Wever J, Muller H, Rechkemmer G. Moderate intervention with carotenoid-rich vegetable products reduces lipid peroxidation in men. J Nutr 2000;130(9):2200-6.

19. Anderson JW, Baird P, Davis RH, Ferreri S, Knudtson M, Koraym A, Waters V, Williams CL. Health benefits of dietary fiber. Nutr Rev 2009;67(4):188-205.

20. Shafaeizadeh S, Jamalian J, Owji AA, Azadbakht L, Ramezani R, Karbalaei N, Rajaeifard A, Tabatabai N. The effect of consuming oxidized oil supplemented with fiber on lipid profiles in rat model. J Res Med Sci 2011;16(12):1541-9.

21. Cao G, Booth SL, Sadowski JA, Prior RL. Increases in human plasma antioxidant capacity after consumption of controlled diets high in fruit and vegetables. Am J Clin Nutr 1998;68(5):1081-7.

22. John JH, Ziebland S, Yudkin P, Roe LS, Neil HA. Effects of fruit and vegetable consumption on plasma antioxidant concentrations and blood pressure: a randomized controlled trial. Lancet 2002;359(9322):1969-74.

23. Fakher SH, Djalali M, Tabei SMB, Zeraati H, Javadi $E$, Sadeghi MR. Effect of vitamin A, E, C and omega-3 fatty acids on lipid peroxidation in streptozotocin induced diabetic rats. Iranian J Publ Health 2007;36(2):58-63.
24. Altomare E, Vendemiale G, Chicco D, Procacci V, Cirelli F. Increased lipid peroxidation in type 2 poorly controlled diabetic patients. Diabete Metab 1992;18(4):264-71.

25. Noberasco G, Odetti P, Boeri D, Malello M, Adezati L. Malondialdehyde (MDA) level in diabetic subjects, relationship with blood glucose and glycosylated hemoglobin. Biomed Pharmacother 1991;45(45):193-6.

26. Pasaoghu H, Sancak B, Bukan N. Lipid peroxidation and resistance to oxidation in patients with type 2 diabetes mellitus. Tohoku J Exp Med 2004;203(3):211-8.

27. Ohmori K, Ebihara S, Kuriyama S, Ugajin T, Ogata M, Hozawa A, Matsui T, Tsubono Y, Arai H, Sasaki $\mathrm{H}$, Tsuji I. The relationship between body mass index and a plasma lipid peroxidation biomarker in an older, healthy Asian community. Ann Epidemiol 2005;15(1):80-4.

28. Olusi SO. Obesity is an independent risk factor for plasma lipid peroxidation and depletion of erythrocyte cytoprotectic enzymes in humans. Int J Obes 2002;26(9):1159-64.

29. Miller ER, Appel LJ, Jiang L, Risby TH. Association cigarette smoking and lipid peroxidation in a controlled feeding study. Circulation 1997;96(4):1097-101.

30. Lykkesfeldt J, Viscovich M, Poulsen HE. Plasma malondialdehyde is induced by smoking: a study with balanced antioxidant profiles. Br J Nutr 2004;92(2):203-6. 